\title{
Fermentation of Rice Straw Using Trichoderma AA1 Mutant With Different Time on Acid Detergent Fiber (ADF) Levels and Neutral Detergent Fiber (NDF)
}

\author{
Sri Sukaryani ${ }^{1}$, Dianto Azar Aswad ${ }^{1}$ dan Engkus Ainul Yakin ${ }^{1}$ \\ Animal Husbandry of Agriculture Faculty, Universitas Veteran Bangun Nusantara \\ Jl. Letjend Sujono Humardani No.1 Kampus Jombor Telp.0271-593156 Sukoharjo \\ Corresponding author : srisukaryani@gmail.com
}

\begin{abstract}
The aims of this research are: 1) to examine the effect of fermentation time on Acid Detergent Fiber (ADF) and Neutral Detergent Fiber (NDF) levels, 2) to assess the optimal time of fermentation in rice straw using Trichoderma mutant AA1. This research uses a directional pattern design RAL with 4 kinds of treatments and 5 replications. The treatments are T0: Fermented rice straw, T1: Fermented rice straw using AA1 mutant Trichoderma for 7 days, T2: Fermented rice straw using Trichoderma AA1 mutant for 14 days, and T3: Fermented rice straw using Trichoderma AA1 mutant for 7 days, T2: Fermented rice straw using Trichoderma AA1 mutant for 14 days, and T3: Fermented rice straw using Trichoderma AA1 mutant for 7 days 21 days. The observed variables are ADF and NDF levels. The data collected is processed statistically using variance analysis and further tests using the Least Significant Difference Test. The length of time of fermentation has a very significant effect on ADF and NDF levels. The lowest levels were achieved by ADF T3 $=33,962 \%$ and the highest at $\mathrm{T} 0=54,911 \%$ as well as the highest NDF levels at $\mathrm{T} 0=64,722 \%$ and the lowest at $\mathrm{T} 3=50,925 \%$. The results of this research can be concluded that the length of 7-21 days fermentation has a very significant effect on ADF and NDF levels and the optimal time is achieved in rice straw fermentation using Trichoderma AA1 mutant for 21 days.
\end{abstract}

Keywords : fermentation, mutant Trichoderma AA1, rice straw

\section{Introduction}

Fodder forage is one of the feed ingredients that are needed by ruminants in Indonesia, so that its availability is expected to be continuously available. On one side, Indonesia is a tropical country that has two kinds of seasons, namely the rainy season and the dry season. During the rainy season forage production of fresh feed is very abundant but during the dry season forage production of fresh feed is difficult to obtain. The situation is an obstacle for ruminants, so it needs to get good handling. Agricultural waste can be used as an alternative forage. Agricultural waste which is widely known and used as animal feed is rice straw.

Rice straw production in Indonesia is very abundant, and the production of rice straw is equivalent to the production of dry rice. In 2017, dry grain production in Indonesia was around 81,382,451 tons. According to the calculation of each ton of dry grain will leave rice straw equivalent to 1 ton, thus it can be said that the production of 
rice straw also reached around 81,382,451 tons. So that the existence of this rice straw can be quite potential in Indonesia. If you see the distribution area of this rice straw is quite wide, so it needs a good management in its utilization.

However, rice straw as a forage forage has a limiting factor in its use as a fodder forage. The limiting factor of rice straw is due to the low crude protein content, high content of crude fiber including ADF and NDF, lignin and cellulose. Rice straw is a low-quality feed ingredient because of the high content of cellulose, hemicellulose, lignin and silica. The high fiber in this straw will prevent the hydrolysis process by microbial enzymes in the rumen, so that it can reduce the level of digestibility. Rice straw is useful as ruminant animal feed as fibrous food, but it has weaknesses because of limiting factors in its utilization.

The problem solving to overcome the limiting factors that exist in rice straw, one of the efforts that can be done is to provide fermentation treatment of rice straw using cellulite microbes and lignocellulitic Trichoderma AA1 mutants.

\section{Materials and Methods}

The research was conducted at the Microbiology Laboratory of Agriculture Faculty, Veteran Bangun Nusantara University of Sukoharjo. The material was used rice straw, urea, drops, starter (Trichoderma AA1 mutant microbial), lime solution. This research was carried out experimentally, with the following treatments:

T0: Fermented rice straw

T1: Rice straw fermented with Trichoderma AA1 mutant for 7 days

T2: Rice straw fermented with Trichoderma AA1 mutant for 14 days

T3: Rice straw fermented with Trichoderma AA1 mutant for 21 days

Before being fermented, firstly the rice straw is soaked in lime solution for 24 hours. Each treatment was repeated on 5 times. The variables were observed Acid Detergent Fiber (ADF) and Neutral Detergent Fiber (NDF). The data collected were analyzed statistically using analysis of variance and if there were differences between treatments a further test was performed with the LSD test.

\section{Result and Discussion}

\section{Levels of Acid Detergent Fiber (ADF)}

Fermented of the rice straw for 7-21 days using Trichoderma AA1 mutant which was previously soaked in lime solution, showed a very significant effect in reducing ADF levels in rice straw. The longer the fermentation time, the lower the ADF content of the rice straw. The lowest mean ADF content was achieved in T3 treatment (fermented rice straw for 21 days) which was $33.962 \%$ and the highest in T0 treatment (unfermented rice straw) was $54.911 \%$. This happens because during the fermentation process, lignocellulose bonds are broken and microbial activity develops and increases cell contents (Akmal, 1994 and Arif, 2001). The longer the fermentation process lasts, the more mushroom growth will grow and develop so that the enzymes that are able to degrade the fiber will be available more and more, so that more fiber in rice straw is degraded (Kasmiran, 2011). In line with the opinion of Sukaryani (2016) that rice straw fermentation for 2 - 6 days using MA-11 which was preceded by soaking rice straw in lime solution can reduce the ADF content from $50.21 \%$ to $36.93 \%$. 
Table 1. ADF levels of fermented the rice straw using Trichoderma AA1 mutant for 7-21 days (\%).

\begin{tabular}{crrrr}
\hline \multirow{2}{*}{ Repetition } & \multicolumn{4}{c}{ Treatments } \\
\cline { 2 - 5 } & T0 & T1 & T2 & T3 \\
\hline 1 & 54.131 & 44.775 & 41.657 & 39.234 \\
2 & 55.590 & 43.310 & 35.253 & 30.568 \\
3 & 54.650 & 46.125 & 43.540 & 31.506 \\
4 & 53.959 & 42.330 & 35.567 & 33.500 \\
5 & 56.224 & 44.037 & 39.004 & 35.001 \\
\hline Total & 274.554 & 220.577 & 195.021 & 169.809 \\
\hline Average & $54.911^{\mathrm{a}}$ & $44.115^{\mathrm{b}}$ & $39.004^{\mathrm{c}}$ & $33.962^{\mathrm{d}}$ \\
\hline
\end{tabular}

Note: Different superscripts on the same line show is very significant difference $(\mathrm{P}<0.01)$

\section{Levels of Neutral Detergent Fiber (NDF)}

The average NDF data of the rice straw fermented with Trichoderma AA1 mutant for 7-21 days is listed in table 2 .

Table 2. Effect of Length of NDF Levels of Fermented the Rice Straw Using Trichoderma AA1 mutant for 7-21 days (\%)

\begin{tabular}{ccccc}
\hline \multirow{2}{*}{ Repetition } & \multicolumn{4}{c}{ Treatments } \\
\cline { 2 - 5 } & $\mathrm{T} 0$ & $\mathrm{~T} 1$ & $\mathrm{~T} 2$ & $\mathrm{~T} 3$ \\
\hline 1 & 65.098 & 57.626 & 53.565 & 50.076 \\
2 & 63.810 & 59.652 & 55.640 & 51.542 \\
3 & 64.729 & 60.800 & 55.765 & 52.320 \\
4 & 65.012 & 58.843 & 54.853 & 50.565 \\
5 & 64.960 & 59.447 & 54.568 & 50.124 \\
\hline Total & 323.609 & 296.368 & 274.391 & 254.627 \\
\hline Average & $64.722^{\mathrm{a}}$ & $59.274^{\mathrm{b}}$ & $54.878^{\mathrm{c}}$ & $50.925^{\mathrm{d}}$
\end{tabular}

Note: Different superscripts in the same column show very significant differences $(\mathrm{p}<0.01)$

Fermentation of rice straw using Trichoderma AA1 mutant for 7-21 days, which was preceded by immersion treatment of rice straw in lime solution for 24 hours, had a very significant effect in reducing NDF levels of rice straw $(\mathrm{P}<0.01)$. Decreased levels of NDF in fermented rice straw occur due to the activity of cellulase enzymes that degrade, loosen and break as well as break down lignocellulosic and lignohemiselulose bonds. Arif (2001), Danang (2014) and Sukaryani (2016) added that the decrease in NDF levels in fermented rice straw due to cellulase enzyme activity in degrading, loosening, breaking and breaking bonds between lignocellulose and lignohemiselulosa thus increasing cell content (NDS). Sukaryani (2016) states that fermentation of rice straw using MA-11 solution can reduce NDF levels from $69.22 \%$ to $62.20 \%$. Yunilas 
(2009) states that a decrease in NDF levels indicates that cellulose cell breakdown has occurred as a result of which feed becomes more easily digested by livestock.

The T3 treatment produced significantly different levels of NDF $(50.925 \%)$ compared to T2 (54.887\%), T1 (59.274\%) and T0 (64.722\%).

\section{Conclusion}

This research can be concluded as follows :

1. Fermented the rice straw using Trichoderma AA1 mutant for 7-21 days has a very significant effect in reducing levels of ADF and NDF rice straw

2. The optimal time to produce the lowest levels of ADF and NDF is achieved in fermentation for 21 days.

\section{References}

Abdullah. 2008. Pembuatan Jerami Padi Amoniasi Sebagai Sumber Pakan Ternak Potensial Di Kecamatan Ujung Loe Kabupaten Bulukumba. Program penerapan IPTEKS.

Arief, R. 2001. Pengaruh Penggunaan Jerami pada Amoniasi terhadap Daya Cerna NDF, ADF, dan ADS Dalam Ransum Domba Lokal. Jurnal Agroland volume 8 (2): $208-215$.

Badan Pusat Statistik, 2016. Produksi Padi, Jagung, Dan Kedelai (Angka Sementara Tahun 2010 dan Angka Ramalan I Tahun 2011).

Danang, B., (2014). Profil Acid Detergent Fiber (ADF) dan Neutral Detergent Fiber (NDF) Produk Fermentasi Jerami Padi Menggunakan Mikrobia Cairan Rumen. Media Sains, Vol. 7 Nomor 1, April 2014.ISSN 2085 - 3548.

Hanafi, N.D,. 2008. Teknologi Pengawetan Pakan Ternak. Departemen Peternakan Fakultas Pertanian Universitas Sumatra Utara. Medan.

Kasmiran A. 2011. Pengaruh Lama Fermentasi Jerami Padi Dengan Mikroorganisme Lokal Terhadap Kandungan Bahan Kering, Bahan Organik, dan Abu. Lentera. Vol. $11.48-52$.

Mulyono A.M.W. 2011. Rancangan percobaan. Progdi Produksi Ternak Fakultas Pertanian. Univet Bantara Sukoharjo. Sukoharjo.

Pamungkas w. 2011. Teknologi Fermentasi, Alternatif Solusi Dalam Upaya Pemanfaatan Bahan Pakan Lokal. Media Akuakultur. Volume 6 Nomor 1:43

Steel, R.G.O and J.H. Torrie, (1980). Principle and Prosedure of Statistics. Mc graw-hill Book Company. Inc. New York.

Sukaryani, S., 2016. Kandungan Serat Jerami Padi Fermentasi Dengan Lama Waktu Inkubasi yang Berbeda. Jurnal Ilmiah Teknosains. Vol 2 No 2. Hal 91 - 94

Yunilas. 2009. Bioteknologi Jerami Padi Melalui Fermentasi Sebagai Bahan Pakan Ternak Ruminansia. Departemen Peternakan Fakultas Peternakan Universitas Sumatera Utara. Medan. 